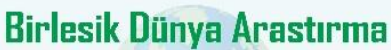 BD-CENTER \\ World Journal on Educational Technology: Current Issues
}

Volume 13, Issue 2, (2021) 288- 296

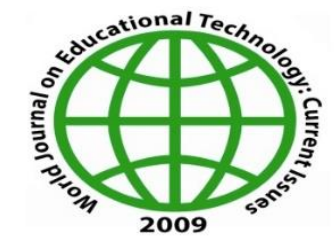

Innovasyon ve Yayıneılık Merkezi

\section{Digital transformation of Russian society as a condition of forming young teachers' professional identity in a big city}

Yury G. Volkov*, Honored Scientist of Russia, Doctor of Philosophical Sciences, Professor, Department of Theoretical Sociology, Institute of Sociology and Regional Studies, Southern Federal University, Rostov-onDon, Russia. https://orcid.org/0000-0001-5696-1570

Galina I. Chikarova, Intern-Researcher, Department of Theoretical Sociology, Institute of Sociology and Regional Studies, Southern Federal University, Rostov-on-Don, Russia https://orcid.org/0000-0002-7499-5472

\section{Suggested Citation:}

Volkov, Y. G. \& Chikarova, G. I. (2021). Digital transformation of Russian society as a condition of forming young teachers' professional identity in a big city. World Journal on Educational Technology: Current Issues. 13(2), 288- 296. https://doi.org/10.18844/wjet.v13i2.5713

Received from January 12, 2021; revised from February 05, 2021; accepted from; April 23, 2021.

Selection and peer review under responsibility of Prof. Dr. Servet Bayram, Yeditepe University, Turkey.

(C2021 Birlesik Dunya Yenilik Arastirma ve Yayincilik Merkezi. All rights reserved.

\begin{abstract}
Digitalization affects every sphere of life including education. However, for it to be beneficial, it needs transfomation in order to fit the current situation or changes that have occurred in human life over a time.The purpose of this research is to consider the impact of the digital transformation of Russian society on the formation of young teachers' professional identity. The constructivist approach and the "soft concepts" of identity that have developed within its framework, serve as the methodological basis of the proposed research. The results of the applied authors' sociological study conducted in 2020 serve as the empirical basis of this study. The method of collecting information was an in-depth interview. The reseach concluded that digitalization has a positive impact on formation of professional identity of young teachers. We also note that, despite the fact that the forced transition to online education has increased the prestige of teaching, digitalization cannot be considered as an independent factor that is able to change the professional space so that it becomes more attractive for young professionals.
\end{abstract}

Keywords: mass digitalization, forced onlineization, digitalization of school education, online education, professional identity, young teachers, Russian megapolis.

\footnotetext{
*ADDRESS OF CORRESPONDENCE: Yury G. Volkov, Honored Scientist of Russia, Doctor of Philosophical Sciences, Professor, Department of Theoretical Sociology, Institute of Sociology and Regional Studies, Southern Federal University, Rostov-on-Don, Russia.

E-mail Address: ugvolkov@sfedu.ru
} 


\section{Introduction}

Digitalization covers all spheres of public life: economy and production; science and education; medicine and the social sphere, as well as daily life of individuals (Keser \& Semerci, 2019; Yehya, 2020; Bakhmat et al., 2020). On one hand, there is a need for the digital transformation of general education system, which sets new conditions for the functioning of modern schools and influences the work of teachers, due to the objective entry of new technologies into the educational process (Castells, 1996). On the other hand, there is a need for digital transformation of the entire Russian society, to deliberate transition of the general education system to new digital technologies (Larionova et al., 2018; Bayanova et al., 2019; Kvon et al., 2019; Griban, Griban \& Korotun, 2019; Piralova et al., 2020; Rubio et al., 2020).

Considering mass digitalization in this paper as a new reality in which the modern teacher is completely immersed, there is a need to note that the level of technical equipment of Russian schools depends on the entire Russian Federation and type of territory in which it is located. For example, municipal schools in big Russian cities and megacities are better equipped than general education institutions in small towns and rural areas, where a large number of state programs and projects are aimed at solving the technical modernization (Passport of the National Project "Education", 2018).

Within the framework of this study, we decided to focus on the impact of digital transformation on formation of professional identity of representatives of a single social and professional group - the young teachers. In many ways, the choice of this group is due to the fact that the digital environment is native to them, as their primary socialization took place in new conditions (Ignatova, 2017; Kvon et al., 2019; Shinkevich et al., 2020; Uzunboylu \& Gundogdu, 2018). The young teachers are also associated with the task of bringing Russian school education to a qualitatively new level, through the conscious use of new technologies (Razumovskaya et al., 2018, 2019; Zyubina et al., 2019; Gazeta pedagogov, 2020).

The issues related to the use of digital devices by schoolchildren and their perception of new digital resources certainly need to be researched. However, within the framework of the proposed study, we treated the digital transformation only in the context of changing conditions and organization of teachers' daily work activities. The aim of this research, therefore, is to consider the impact of the digital transformation of Russian society on the formation of young teachers' professional identity.

\section{Research Methodology}

Professional identity of young teachers is defined in the work through the identity concept: the identity of the young teacher with himself as a professional and with the reference of professional group. The structure of professional identity included 7 structural components, including assessment of professional status, the place of professional identity in the overall structure of social identity, corporate identity, professional values, satisfaction with the profession, work motivation, and professional strategies. The instrumental concept of "young teacher", which is used in this study, is as follows: a young teacher is a specialist who has been working in general education system for less than 5 years and whose age does not exceed 30 years.

The methodological basis that guides us in studying professional identity of young teachers is the constructivist approach and the "soft concepts" of identity developed by Brubaker and Cooper (2000), which allow us to consider professional identity of young teachers not as a stable "I-concept" core, which persists from beginning to end, despite external vicissitudes, but as something mobile, formed under the influence of various factors and constantly changing (depending on the context). 
In this regard, from a research point of view it is important to solve the problems related to identifying some trends in digital transformation of Russian society and the general education system (analysis of planned and forced scenarios) and to consider the impact of these transformational processes on the formation of young teachers' professional identity in a big Russian city. To achieve this goal and to solve the research problems, we used the principles of phenomenological approach and the methods of theoretical interpretation of empirical data.

The results of our applied sociological study (conducted in the summer of 2020) served the empirical basis of the study. The method of collecting empirical data was an in-depth interview with young teachers of municipal Rostov-on-Don secondary schools. The sample was constructed using the elements of "eight-window sample model for research interviews" (Steinberg, 2014) and included 16 young teachers from Rostov-on-Don. The main parameters that allowed us to form the necessary sample set were as follows: basic pedagogical education; professional success, which includes both an objectively recorded high result of the professional work of the teacher himself and his pupils.

In addition to the indicated main parameters used in selection of the sample, at the stage of selecting informants for in-depth interviews, such parameters as gender, the profile of the discipline (humanities/natural sciences), as well as representation of primary school teachers in the sample, the type of educational organization (school/gymnasium, lyceum) were also considered.

\section{Results and Discussion}

The trends of digital transformation of the Russian society and the general education system are (according to most experts) a necessary condition for development of the national educational space in the context of transition to the digital economy. The key areas of development are creation of a digital educational environment, revision of the content of education, creation of a flexible school management system and personalized educational process, introduction of new forms of educational practices, methods and technologies (National Project "Education", 2018).

During the interview, young teachers noted that "electronic devices and gadgets surround us everywhere. We have smart refrigerators, smart air conditioners, and children are used to these objects surrounding them in everyday life" (man, natural science, 27 years old, 4 years' experience), and the school environment cannot be an exception. The use of everyday information resources familiar to children is of particular interest, which has a positive effect on the educational process, its results and, as a consequence, on professional identity of teachers (strengthening it through emotional satisfaction from professional work and its results), which is an important component of professional selfdetermination.

The following statement of one of the participants can most clearly illustrate this thesis: "You visit YouTube. Kids: Oh! YouTube! They already know everything about me. And you find there the techniques of multiplying 3 by 3, roughly speaking, the topic. And there are such wonderful video lessons, a cartoon lesson, an info lesson, where in a game form, in an interactive form, there are a lot of different tasks and some logical puzzles, non-standard tasks. Not just apples and pears in a car, but something more interesting, more modern " (women, primary classes, 25 years old, 4 years' experience). These findings corroborate with the finding of Tavoosy (2018), Soylucicek (2019) and Tavasoli, Mowlaie, Majid \& Rahimi (2020).

It is also important to note that all the young teachers agreed that "You need to clearly understand what kind of technology you use (Yoruk \& Sekerci, 2020). When you show them a presentation, for the sake of the presentation itself, and the same information is in the textbook, it is 
probably more logical to show it in the textbook. This is also less harmful for your health and in general you do not lose anything. And if this is some kind of interactive format and you do not reveal this topic in another way, then of course you need to use some digital technology or a form of working in a group, and so on" (man, humanitarian, 28 years old, 5 years' experience).

The participants of the study in their interviews repeatedly stressed that digital technologies help them in explaining material: "Personally, I like interactive whiteboards and presentations more, because it is a visual series - they remember, and I teach the lesson, explain the material, what is what and why" (man, humanitarian profile, 26 years old, 4 years' experience); "It is much easier for me when there is some way to at least show something on the screen, because, for example, the books that you have, some disks are usually attached to them. You turn on this disc, and there is a topic. And there somebody tells all this to them, and after that you talk to children - what is clear, what is not clear once again" (women, primary classes, 25 years, 4 years' experience).

The results of the study also show that the constructive potential of the mass use of digital technologies in educational space allows the reduction of the level of labor costs in preparation of the lesson and its conduct: "All that certainly makes it easier. There is no such thing that I came in the evening and began to drip to look for some resource there. I have a 20-minute break, I looked so briefly, like it or not like it. And then decide in the same flow. In fact, it is remarkably interesting, the children really like these lessons" (women, primary classes, 25 years, 4 years' experience), to level out the risks faced by all the teachers, regardless of their experience, associated with an increased level of accountability and excessive bureaucratization (Klimenko, 2018).

The special IT programs available in the information environment, which are actively used by young teachers to facilitate implementation of these routine types of professional activities can minimize the destructive impact on formation of their professional identity. For example, young teachers have repeatedly noted that they actively use digital technologies in various types of reports by downloading the necessary information from the general data system or previously prepared reporting documentation: "Of course it makes it easier! They have heard about it and taught us how to write all the reports, which we now do at once, changing the numbers, but they used to write it all by hand every time. Naturally, this is a huge work and now life has become much easier for us in this regard" (women, natural science, 24 years old, 1 year experience).

However, it is important to note those who share the position that the confident use of new technologies ensures the use of information resources in the classroom without increasing the preparation time for a particular lesson: "In general, in fact, anyone who knows how to use the Internet knows that you can find a large number of presentations on the necessary lessons and just change them for yourself <...> Labor costs have not increased much" (man, humanitarian profile, 26 years, 4 years' experience). Among the young teachers there are also those who note the increase in time when using new technologies "Preparing presentations is a big time, if we say that taking ready-made presentations and processing them is a big time. If you create it yourself - this is also a catastrophically long time" (man natural science profile, 23 years old, 2 years' experience).

The teachers have repeatedly noted: "we have to work both ways. More work only" (women, natural science profile, 24 years old, 2 years' experience). "Sometimes you sit and duplicate the same magazine in a paper version, because the Internet freezes, or the computer also hangs a little. Sometimes you must do double work: first put down the marks in paper form, and after school you sit down and transfer everything into the E-form. Let us just say that every second I put an assessment, and it's all preserved, this, unfortunately, often does not happen, we have to duplicate it." (women, primary classes, 
26 years old, 4 years' experience). This may be partly due to the insufficient development of Russian schools' infrastructure, even in big cities.

Considering the impact of digital transformation on formation of professional identity of young teachers, it is impossible to avoid studying this issue in the context of new social reality caused by the spread of COVID-19 and the associated forced "onlineization" (Lubsky \& Kovalev, 2020) of the entire educational process in the spring of 2020.

It was found that the possibility of using online technologies for educational process allowed teachers to maintain their jobs and wages, which is positively noted by young teachers: "Many people have lost their jobs in the pandemic, they lost their income, but with distance learning teachers have lost absolutely - absolutely, nothing. This stability is also especially important, especially in a society like this" (man, humanitarian, 28 years old, 5 years' experience). This finding corroborates with the findings of Higueras-Rodriguez \& Medina-Garcia, (2020).

The forced digitalization has also had a constructive impact on such a structural component of professional identity as the prestige of profession in society (Nurzhanov, et al., 2021). Before the pandemic, young teachers repeatedly complained about devaluation of the teacher status in modern Russian society (Chikarova, 2018). This was considered by researchers as a destructive factor that hinders formation of a stable positive professional identity of teachers. But in the interviews conducted after the experience of forced onlineization, teachers noted that it was the pandemic that allowed them to raise the status of their profession in the eyes of parents of pupils, allowing them to directly attend classes and observe the work of teachers. This finding is similar to the findings of Kiracioglu, DemirbasCelik \& Aytaç (2019).

This practice can also be considered as a factor minimizing the risk associated with difficulties in "teacher-parent" interaction, which usually arise due to the fact that "parents do not always properly deal with their children, and the child is not always really ready for lessons, pedagogically unsupervised, and so on", they do not understand that "yes, the teacher must teach, but the educational institution has its own laws and requirements in order to work in this field" (man, humanitarian profile, 26 years old, 4 years' experience).

The new social reality has also allowed young teachers to feel their greater competitiveness in the field of professional activity in comparison with older teachers: "In general, yes, online education has more opportunities for young teachers than for the elderly" (man, humanitarian profile, 29 years old, 5 years' experience). The abrupt transition to the online space was caused by a whole complex of difficulties: "yes, indeed, young people here have a certain head start, that is, the ball is on their side, because indeed, the older the age, the harder is the teacher to become friends with technology" (man, humanitarian, 29 years old, 5 years' experience). The teachers noted that "there are a lot of new things that need to be done with the computer, everything that can be done using the Internet and it is not particularly difficult for us, again, for the young teachers, and those who are older, especially in distance learning - it was very difficult for them to cope with all this. They are very distantly familiar with it" (women, natural science, 24 years old, 1 year experience).

It is impossible not to say that the digital transformation has led to the fact that the Internet space has become a place where individuals, just as in the real world, build their own model of behavior, form an identity that sometimes differs so much from the one in the real world (Hermanto, Rai \& Fahmi, 2021). 
In the course of the study, it was found that many young teachers do not position themselves as teachers on the Internet (Rababah, 2021). However, in view of the full transparency of private life due to the active management of modern young people of their social networks, public opinion plays a huge role. This is reflected in behavior of young teachers on the Internet and cannot but affect their professional identity. "Let us just say, on the one hand, both yes and no, because I do not run a purposeful teacher blog, but given that I am a teacher, I so say filter the content that I can expose. That is, some things that are acceptable for the manager, who can put some photos from the rest here or there in swimsuits, I do not put this up, realizing that well, you never know who can visit my page. I try to avoid any incriminating things coming out of my mouth on social networks" (women, primary school, 26 years old, 4 years' experience).

Special attention is also drawn to the fact that almost all the young teachers who took part in the study, in their interviews said that the mass digitalization of Russian society and, as a result, development of digital infrastructure in Russian schools is not a factor that can have a proper constructive impact, ensuring formation of a stable structure of professional identity for the young teachers, contributing to their long-term integration into the field of professional activity.

When answering the question: "In your opinion, will the digitalization of education and innovative equipment of schools serve to attract young professionals? Will the mass digitalization affect the ratio of young and experienced teachers?", the informants replied that "It will not affect much, because those who wants to go to work in school, in principle, go to our ridiculous salaries, and digitalization can probably be promoted, but now probably in all the areas of digitalization in medicine and science and everywhere. It seems to me that it will not play a significant role" (women, primary classes, 26 years old, 4 years' experience). "I don't think it will have any effect. My opinion is that this is not the point that will attract young teachers" (women, natural science, 24 years, 1 year experience).

\section{Conclusion}

Thus, we can conclude that digitalization of school education has recently been increasing, which is more in tune with representatives of the younger generation of Russian teachers, due to their generational characteristics associated with primary socialization in digital society. While representatives of the older generation (experienced teachers) perceive these innovations as additional barriers, young teachers see them as new opportunities in the field of professional activity. The research found that at present, the trends of digital transformation of the general education system will be both gradual (planned) and emergency (forced), caused by the spread of a new coronavirus infection and new social realities of the general education system.

On the one hand, the results obtained in the course of the study suggest that digital transformation has a constructive impact on formation of professional identity of young teachers, since in full-time conditions it allows, firstly, to optimize the daily work and thereby neutralize some of the risks associated with an increase in the workload of teachers, and secondly, to increase the level of their own professionalism and the quality of educational process. Also, the forced "onlineization" of educational process has made it possible to raise the status of the teacher profession and to argue for the viability of using all the benefits of digitalization in the learning process.

On the other hand, the research allowed us to establish that the trends of digital transformation of Russian society as a condition for the formation of professional identity of teachers in a big Russian city are not sufficient for effective integration of young teachers in the field of professional activity and further successful professional development. 
Volkov, Y. G. \& Chikarova, G. I. (2021). Digital transformation of Russian society as a condition of forming young teachers' professional identity in a big city. World Journal on Educational Technology: Current Issues. 13(2), 288- 296. https://doi.org/10.18844/wjet.v13i2.5713

\section{Acknowledgments}

The reported study was funded by RFBR, project number19-311-90073.

\section{References}

Bakhmat, N., Liubarets, V.., Bilynska, M.., Ridei, N.., \& Anhelina, S. (2020). Digital transformation of preparation of the future: Specialists in the economic industry in conditions of dual professional education. New Trends and Issues Proceedings on Humanities and Social Sciences, 7(3), 242-251. https://doi.org/10.18844/prosoc.v7i3.5258

Bayanova, A.R., Kuznetsov, V.V., Merculova, L.V., Gorbunova, L.N., Pervozvanskaya, O.A., Shalamova, O.O. \& Vorobyova, C.I. (2019). Student Performance Interrelation with Gadget Use at Lessons. Journal of Environmental Treatment Techniques, 7(3), 432-437. https://tinyurl.com/ydluvgq3

Brubaker, R. \& Cooper, F. (2000). Beyond «Identity». Theory and Society, 29(1), 1-47. http://pascalfrancis.inist.fr/vibad/index.php?action=getRecordDetail\&idt=1550369

Castells, M. (1996). The Rise of the Network Society. Wiesbaden: VS Verlag für Sozialwissenschaften. https://tinyurl.com/vib8sbkb

Chikarova, G.I. (2018). Prestige and Motives of Choosing Profession in Assessments of Young Teachers of Rostovon-Don. Gumanitarij Juga Rossii, 7(6), 200-211.

Gazeta pedagogov. (2020). Seven signs of the Teacher of the Future. URL: https://gazeta-pedagogov.ru/7priznakov-uchitelya-

budushhego/?utm source=rassylka\&amp;utm medium=cpc\&amp;utm campaign=anons\&amp;utm con tent=7-priznakov

Griban, O. N., Griban, I. V., \& Korotun, A. V. (2019). Modern teacher under the conditions of digitalization of education. In 1st International Scientific Conference" Modern Management Trends and the Digital Economy: from Regional Development to Global Economic Growth"(MTDE 2019) (pp. 604-607). Atlantis Press. https://dx.doi.org/10.2991/mtde-19.2019.121

Hermanto, H., Rai, N. G. M., \& Fahmi, A. (2021). Students' opinions about studying from home during the COVID19 pandemic in Indonesia. Cypriot Journal of Educational Sciences, 16(2), 499-510. https://doi.org/10.18844/cjes.v16i2.5627

Higueras-Rodriguez, L., \& Medina-Garcia, M. (2020). Active methodologies as a key element in teacher training for educational inclusion. New Trends and Issues Proceedings on Humanities and Social Sciences, 7(3), 13-19. https://doi.org/10.18844/prosoc.v7i3.5227

Ignatova, N.Yu. (2017). Digital Natives: View from the Outside. Socio-humanitarian Problems of Informatization of Education. URL: http://journals.tsu.ru/uploads/import/1553/files/65 065.pdf

Keser, H., \& Semerci, A. (2019). Technology trends, Education 4.0 and beyond. Contemporary Educational Research Journal, 9(3), 39-49. https://doi.org/10.18844/ceri.v9i3.4269

Kiracioglu, D., Demirbas-Celik, N., \& Aytaç, P. (2019). Effectiveness of family involvement activities in pre-school education. Global Journal of Guidance and Counseling in Schools: Current Perspectives, 9(3), 131-137. https://doi.org/10.18844/gigc.v9i3.4489

Klimenko, L.V. (2018). Professional Identity of Representatives of Socially Oriented Professions in the Conditions of Russian Society Precariatization. Rostov-on-Don: Fond nauki $i$ obrazovanija. https://ideas.repec.org/a/nos/voprob/2018i3p36-67.html 
Volkov, Y. G. \& Chikarova, G. I. (2021). Digital transformation of Russian society as a condition of forming young teachers' professional identity in a big city. World Journal on Educational Technology: Current Issues. 13(2), 288- 296. https://doi.org/10.18844/wjet.v13i2.5713

Kvon, G.M., Vaks, V.B., Kalimullin, A.M., Bayanova, A.R., Shaidullina, A.R., Dolzhikova, A.V. \& Lapidus, N.I. (2019). Developing the Informational and Digital Environment of a University: Problem Analysis and Assessment. Eurasia Journal of Mathematics, Science and Technology Education, 15(10), 1841-1848. https://doi.org/10.29333/ejmste/109503

Larionova, A.A., Zaitseva, N.A., Anoshina, Y.F., Gaidarenko, L.V., \& Ostroukhov, V.M. (2018). The modern paradigm of transforming the vocational education system. Astra Salvensis, 6, 436-448. https://www.ceeol.com/search/article-detail?id=681540

Lubsky, A.V. \& Kovalev, V.V. (2020). From "Onlinization" of Higher School to Online Education. Gumanitarij Juga Rossii, 9(2), 33-50.

National Project "Education". (2018). National Project. URL: https://edu.gov.ru/national-project

Nurzhanov, C.., Pidlisnyuk, V., Naizabayeva, L., \& Satymbekov, M. (2021). Research and trends in computer science and educational technology during 2016-2020: Results of a content analysis. World Journal on Educational Technology: Current Issues, 13(1), 115-128. https://doi.org/10.18844/wjet.v13i1.5421

Passport of the National Project "Education". (2018). Passport of the National Project approved by the Presidium of the Council under the President of the Russian Federation for Strategic Development and National Projects (Protocol No. 16 of December 24, 2018). URL: http://government.ru/projects/selection/741/35566/

Piralova, O.F., Gerasimenko, S.A., Kuznetsov, V.V., Popova, O.V., Subbotin, G.V., Kolomyts, O.G., \& Mashkin, N.A. (2020). Gaming Industry Trends in new Generation Specialist Training in University Environment. Journal of Environmental Treatment Techniques, 8(3), 1132-1135. https://tinyurl.com/vzr6dzh9

Rababah, E. Q. (2021). From theory to practice: Constructivist learning practices among Jordanian kindergarten teachers. Cypriot Journal of Educational Sciences, 16(2), 612-626. https://doi.org/10.18844/cjes.v16i2.5639

Razumovskaya, M., Zaitseva N.A., Larionova, A.A., Chudnovskiy, A.D., \& Breusova, E.A. (2018). Prospects for applying various forms of organizational integration to improve the quality of education. Astra Salvensis, 6 , 348-362. https://www.ceeol.com/search/article-detail?id=681325

Razumovskaya, M.I., Larionova, A.A., Zaitseva, N.A., Petrina, O.A, Vinogradova, M.V., Nagay, N.G., \& Takhumova, O.V. (2019). Models of Integrated Interactions Organization in the Field of Environmental Education. Journal of Environmental Treatment Techniques (JETT), 7(4), 576-580. https://tinyurl.com/vifs3l7f

Rubio, G.L., Leskova, A., Prokopyev, A.I., Miroshkin, D.V., \& Kamneva, E.V. (2020). Despair or the loss of selfhood in Kierkegaard's sickness unto death. XLinguae, 13(3), 63-77. https://philpapers.org/rec/LEIDOT-3

Shinkevich, M.V., Mashkin, N.A., Ishmuradova, I.I., Kolosova, V.V., \& Popova, O.V. (2020). Management of sustainable consumption of energy resources in the conditions of digital transformation of the industrial complex. International Journal of Energy Economics and Policy, 10(5), 454-460. https://doi.org/10.32479/ijeep.10202

Soylucicek, S. (2019). Looking through the Sphere; Illustration in virtual reality. Global Journal of Arts Education, 9(1), 22-28. https://doi.org/10.18844/gjae.v9i2.3953

Steinberg, I. E. (2014). A logical scheme to justify the sample in qualitative interview: An "8-window sample model". Sotsiologiya: metodologiya, metody, matematicheskoye modelirovaniye, 38-71

Tavasoli, M. R., Mowlaie, B., Majid, M. A., \& Rahimi, A. (2020). The comparative effects of different gloss types through screencast on vocabulary learning and working memory of Iranian EFL learners. International Journal of New Trends in Social Sciences, 4(1), 10-24. https://doi.org/10.18844/ijntss.v4i1.4809

Tavoosy, Y. (2018). The effect of digital storytelling on EFL learners' productivity motivation. International Journal of Learning and Teaching, 10(2), 116-125. https://doi.org/10.18844/ijlt.v10i2.3406 
Uzunboylu, H., \& Gundogdu, E. G. (2018). A Content Analysis Study on Pre-School Education and Instructional Technologies. International Journal of Innovative Research in Education, 5(4), 119-128. https://doi.org/10.18844/ijire.v5i4.3974

Yehya, F. M. (2020). Promoting Technology- Implementation Learning paradigm for online learning in secondary Education. Global Journal of Information Technology: Emerging Technologies, 10(1), 12-21. https://doi.org/10.18844/giit.v10i1.4620

Yoruk, T., \& Sekerci, R. (2020). The views of shareholders on utilization of educational technologies in adult learning. World Journal on Educational Technology: Current Issues, 12(4), 248-257. https://doi.org/10.18844/wjet.v12i4.5141

Zyubina, I., Dzyubenko, A., Borisenko, V., Popova, O., \& Prokopyev, A. (2019). Implicit linguopragmatic strategies of speech behavior of English-speaking prosecutors. XLinguae, 12(4), 92-102. https://www.rea.ru/ru/org/managements/orgnirupr/Documents/666-

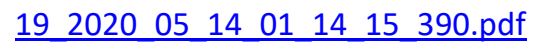

